\title{
Isolation and characterization of cytotoxic compounds from Euphorbia clementei Boiss.
}

Abbes Benmerachea,b, Abdulmagid Alabdul Magid ${ }^{\mathrm{b},}$, Amira Labed ${ }^{\mathrm{a}}$, Ahmed Kabouche ${ }^{\mathrm{a}}$, Laurence VoutquenneNazabadioko $^{\text {b }}$, Jane Hubert ${ }^{\mathrm{b}}$, Hamid Morjani ${ }^{\mathrm{c}}$, Zahia Kabouche ${ }^{\mathrm{a}}$

aUniversité des frères Mentouri-Constantine, Département de chimie, Laboratoire d'Obtention des Substances Thérapeutiques (LOST), Campus Chaabet-Ersas, 25000 Constantine, Algeria

bICMR-UMR CNRS 7312, Groupe Isolement et Structure, Campus Sciences, Bât. 18, BP 1039, 51687 Reims, France

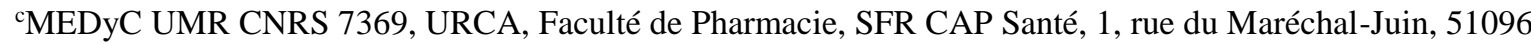

Reims, France

* Corresponding author. Tel.: +33-3-26-91-82-08; fax: +33-3-26-91-35-96. E-mail address: abdulmagid.alabdulmagid@univ-reims.fr (A. Alabdul Magid)

\begin{abstract}
A new phorbol-type diterpene ester, 4,20-dideoxy- $4 \alpha$-phorbol-12 $\beta$-acetate- $13 \alpha$-isobutyrate, in addition to eleven known compounds were isolated from the latex and roots of Euphorbia clementei Boiss. Structure elucidation was performed by comprehensive $1 \mathrm{D}$ and $2 \mathrm{D}$ NMR analyses $\left({ }^{1} \mathrm{H}\right.$ and ${ }^{13} \mathrm{C}$ NMR, COSY, ROESY, HSQC and HMBC experiments), mass spectrometry (HR-ESI-MS), and by comparison with literature data. The inhibitory activity of all isolated compounds was evaluated against promyelocytic leukemia HL60 and human erythromyeloblastoid leukemia K562 cell lines and seven of these compounds exhibited a weak cytotoxicity with $\mathrm{IC}_{50}$ values ranging from 40 to $97 \mu \mathrm{M}$.
\end{abstract}

Keywords: Euphorbia clementei; Euphorbiaceae; diterpenoids; triterpenoids; cytotoxic activity.

\section{Introduction}

There are about 2000 Euphorbia species (Euphorbiaceae) worldwide, ranging from annual weeds to trees (Jassbiet, 2006), cosmopolitan in distribution, particularly in Africa and Central and South America (El-sherei et al., 2015). Euphorbia plants are a rich source of diterpenoids and triterpenoids (Deng et al., 2010, Haba et al., 2007, Hohmann et al., 2001, Li et al., 2015, Sobottka et al., 2016, Wang et al., 2015a, 2015b). Some Euphorbia species are used in folk medicines even though; toxicity was reported to some of them (Singla and Pathak, 1990, Fatope et al., 1996, Yang et al., 2014). Diterpenoids have been suggested as the main chemical constituent responsible for the activities of Euphorbia species as the antitumor (Pusztai et al., 2007), antiproliferative, cytotoxic (Shadi et al., 2015, Wang et al., 2015b, Wang et al., 2015, Wang et al., 2016, Zhang et al. 2012), antiinflammatory (Wan et al., 2016), antiviral (Yang et al., 2005), and multidrug resistance (Duarte et al., 2007).

About 40 Euphorbia species are found in Algeria (Quezel and Santa, 1963) among which Euphorbia clementei Boiss. This perennial herbaceous plant is endemic to Aures region and grows in dry rockery areas. Its leaves are glabrous, ovoid to lanceolate and possess a serrulate margin. The involucral glands are subrounded and the capsule $(3-5 \mathrm{~mm})$ is warty (Quezel and Santa, 1963).

In the present work, a new phorbol-type diterpene ester 1, along with eleven known compounds 2-12, were isolated from E. clementei growing wild in Aures (North Eastern Algerian), and their structures were elucidated on the basis of detailed NMR and mass spectrometry analyses. Since Euphorbia diterpenoids and triterpenoids are known to have cytotoxic activity (Wang et al., 2016), the inhibitory activity of compounds 1-12 was tested against promyelocytic leukemia HL60 and human erythromyeloblastoid leukemia K562 cancer cell lines using the standard MTT assay.

\section{Results and discussion}

Repetitive chromatographic purification of the latex and the trichloromethane extracts of the roots of $E$. clementei resulted in the isolation of a new diterpenoid (1) and eleven known compounds (212). The known compounds were identified as cycloartenol (2) (De Pascual Teresa et al., 1987), 24-methylene cycloartanol (3) (Ghanadian et al., 2015), 24-methylene cycloartan-3 $\beta, 25$-diol (4) 
(Abdel-Monem et al., 2008), cycloeucalenol (5), obtusifoliol (6) (Mohan et al., 1990), $\beta$-sitosterol (7) (Chaturvedula and Prakash., 2012), cycloart-22Eene-3 $\beta, 25$-diol $\quad(8), \quad(3 \beta, 9 \beta, 24 R) \quad 9,19$ cyclolanostane-3,24,25-triol (9) (Ghanadian et al., 2015), 1-methyl-cyclobutene (10) (Mohd Nasuha and Choo, 2015), $\alpha$-terpineol (Consolacion et al., 2013) (11) and cycloartenyl acetate (12) (De Pascual Teresa et al., 1987) (Fig. 1).

The HR-ESI-MS spectrum of compound $\mathbf{1}$ exhibited the ion peak $[\mathrm{M}+\mathrm{Na}]^{+}$at $\mathrm{m} / \mathrm{z}$ 467.2404. Analysis of the NMR data revealed characteristic signals for an isobutyryl residue $\left[\delta_{\mathrm{C}} 181.0\left(\mathrm{C}-1^{\prime \prime}\right)\right.$, $34.3\left(\mathrm{C}-2^{\prime \prime}\right), 18.5\left(\mathrm{C}-3^{\prime \prime}\right)$ and $\left.18.7\left(\mathrm{C}-4^{\prime \prime}\right)\right]$ and an acetyl group $\left[\delta_{\mathrm{C}} 170.6\left(\mathrm{C}-1^{\prime}\right)\right.$ and $\left.21.1\left(\mathrm{C}-2^{\prime}\right)\right]$. The NMR data of 1 showed also signals for an $\alpha, \beta$ unsaturated carbonyl groups, as well as trisubstituted double bond, five methines, one oxymethine, one methylene and five methyl groups (see experimental section). Comprehensive 1D and 2D NMR analyses $\left({ }^{1} \mathrm{H}\right.$ and ${ }^{13} \mathrm{C}$ NMR, COSY, ROESY, HSQC and HMBC experiments) established that compound $\mathbf{1}$ was a diterpenoid of the tigliane family (Aichour et al., 2014, Wu et al., 1994). The COSY correlations H-1/H-10, associated with HMBC correlations $\mathrm{H}-1 / \mathrm{C}-4, \mathrm{C}-9$ and $\mathrm{C}-10$ and $\mathrm{H}_{3}-19 / \mathrm{C}-1, \mathrm{C}-2$ and $\mathrm{C}-3$ confirmed the presence of the methyl-substituted five membered ring-A incorporating an $\alpha, \beta$-conjugated ketone moiety. HMBC correlations from the methylene signals $\left(\mathrm{CH}_{2}-5\right)$ to $\mathrm{C}-4, \mathrm{C}-7$ and $\mathrm{C}-10$ helped define the junction of rings $\mathrm{A}$ and $\mathrm{B}$. Correlations from the methyl singlet at $\delta_{\mathrm{H}} 1.77$ $\left(\mathrm{CH}_{3}-20\right)$ to $\mathrm{C}-5, \mathrm{C}-6$ and $\mathrm{C}-7$ allowed us to place this $\mathrm{CH}_{3}-20$ in position 6 and confirmed the location of the C-6/C-7 double bond. The ring $\mathrm{C}$ and its junction to ring $\mathrm{B}$ was elucidated from COSY correlations $\mathrm{H}_{3}-18 / \mathrm{H}-11, \mathrm{H}-11 / \mathrm{H}-12$, and $\mathrm{H}-$ 8/H-14, and from HMBC correlations $\mathrm{H}_{3}-18 / \mathrm{C}-9$ and $\mathrm{C}-12$. The cyclopropyl ring-D with gemdimethyl substitution was established on the basis of the mutual correlations between the two methyl groups $\left(\mathrm{H}_{3}-16\right.$ and $\left.\mathrm{H}_{3}-17\right)$ both also showing correlations with $\mathrm{C}-13, \mathrm{C}-14$ and $\mathrm{C}-15$. The $12-O$ acetyl group was evidenced by the HMBC correlation from $\mathrm{H}-12$ to its carbonyl carbon $\left(\delta_{\mathrm{C}}\right.$ 170.6). The presence of $9-\mathrm{OH}$ and 13-O(isobutyryl) groups was indicated by the chemical shifts of C-9 $\left(\delta_{\mathrm{C}} 78.0\right), \mathrm{C}-12\left(\delta_{\mathrm{C}} 76.1\right)$, and C-13 $\left(\delta_{\mathrm{C}}\right.$ 64.9) and by comparison with known tigliane analogues possessing the same substitution patterns
(Aichour et al., 2014). The relative configuration of 1 was characterized by NMR comparison to 4,20dideoxy-4 $\alpha$-phorbol-12-benzoate-13-isobutyrate (Aichour et al., 2014) and analysis of ROESY data. The difference between these two compounds was attributable to the $O$-substituents at C-12 and C-13 and the remaining structural parts displayed highly comparable NMR data, which suggested that the two molecules possessed the same relative configuration. Moreover, the ROESY correlations between $\mathrm{H}-10 / \mathrm{H}-4$ and $\mathrm{H}-10 / \mathrm{H}-18$ suggested that they were pseudo-axially bonded and $\alpha$-oriented, while those of $\mathrm{H}-8 / \mathrm{H}-11, \mathrm{H}-8 / \mathrm{H}_{3}-17$, and $\mathrm{H}-7 / \mathrm{H}-14$ supported the $\beta$-direction of $\mathrm{H}-8, \mathrm{H}-11$ and the cyclopropyl moiety. A typical vicinal coupling constant value of $10.4 \mathrm{~Hz}$ between the trans-diaxial $\mathrm{H}-11$ and H-12 confirmed that the acetyl group at C-12 is $\beta$-oriented (Zhang et al., 2012). All phorbol derivatives isolated from Euphorbiaceae family possess the configuration $\beta$ for $\mathrm{H}-8$ and $\mathrm{H}-11$ whereas the configuration $\alpha$ was assigned to $\mathrm{H}-10$, H-14 and hydroxyl groups at C-9 and C-13 (Aichour et al., 2014, Alberto Marco et al., 1999, El-sherei et al., 2015, Haba et al,. 2013). So, on a biogenetic basis, the same stereochemistry is assumed for these compounds which constitute a common stereochemical group. The structure of $\mathbf{1}$ was thus unambiguously characterized as 4,20dideoxy- $4 \alpha$-phorbol-12 $\beta$-acetate- $13 \alpha$-isobutyrate.

\begin{tabular}{|c|c|c|}
\hline & $\delta_{\mathrm{H}} \mathrm{m}(J \mathrm{~Hz})$ & $\delta_{\mathrm{C}}$ \\
\hline 1 & $7.20(\mathrm{~s}, \mathrm{H}-1)$ & $155.6(\mathrm{C}-1)$ \\
\hline 2 & - & $143.7(\mathrm{C}-2)$ \\
\hline 3 & - & $212.0(\mathrm{C}-3)$ \\
\hline 4 & $2.72(\mathrm{dt}, J=4.2$ and $6.3 \mathrm{~Hz}, \mathrm{H}-4)$ & $49.3(\mathrm{C}-4)$ \\
\hline \multirow[t]{2}{*}{5} & $2.38(\mathrm{dd}, J=15.4$ and $4.7 \mathrm{~Hz}, \mathrm{H}-5 \mathrm{a})$ & $30.0(\mathrm{C}-5)$ \\
\hline & 3.45 (brd, $J=15.4 \mathrm{~Hz}, \mathrm{H}-5 \mathrm{~b})$ & \\
\hline 6 & - & $124.3(\mathrm{C}-6)$ \\
\hline 7 & $4.75(\mathrm{~s}, \mathrm{H}-7)$ & $134.2(\mathrm{C}-7)$ \\
\hline 8 & $1.90(\mathrm{~s}, \mathrm{H}-8)$ & $40.9(\mathrm{C}-8)$ \\
\hline 9 & $5.20(\mathrm{~s}, \mathrm{H}-9)$ & $78.0(\mathrm{C}-9)$ \\
\hline 10 & $3.42(\mathrm{~m}, \mathrm{H}-10)$ & $47.1(\mathrm{C}-10)$ \\
\hline 11 & $1.70(\mathrm{dd}, J=10.4$ and $6.2 \mathrm{~Hz}, \mathrm{H}-11)$ & $43.2(\mathrm{C}-11)$ \\
\hline 12 & $5.45(\mathrm{~d}, J=10.4 \mathrm{~Hz}, \mathrm{H}-12)$ & $76.1(\mathrm{C}-12)$ \\
\hline 13 & - & $64.9(\mathrm{C}-13)$ \\
\hline 14 & $1.74(\mathrm{~d}, J=5.1 \mathrm{~Hz}, \mathrm{H}-14)$ & $37.6(\mathrm{C}-14)$ \\
\hline 15 & - & $25.4(\mathrm{C}-15)$ \\
\hline 16 & $1.23(\mathrm{~s}, \mathrm{H}-16)$ & $16.4(\mathrm{C}-16)$ \\
\hline 17 & $1.20(\mathrm{~s}, \mathrm{H}-17)$ & $24.2(\mathrm{C}-17)$ \\
\hline 18 & $1.09(\mathrm{~d}, J=6.2 \mathrm{~Hz}, \mathrm{H}-18)$ & $11.9(\mathrm{C}-18)$ \\
\hline 19 & $1.82(\mathrm{~s}, \mathrm{H}-19)$ & $10.5(\mathrm{C}-19)$ \\
\hline 20 & $1.77(\mathrm{~s}, \mathrm{H}-20)$ & $28.9(\mathrm{C}-20)$ \\
\hline \multicolumn{3}{|c|}{ Acetate } \\
\hline $1^{\prime}$ & - & $170.6\left(\mathrm{C}-1^{\prime}\right)$ \\
\hline $2^{\prime}$ & $2.15\left(\mathrm{~s}, \mathrm{H}-2^{\prime}\right)$ & $21.1\left(\mathrm{C}-2^{\prime}\right)$ \\
\hline \multicolumn{3}{|c|}{ Isobutyrate } \\
\hline $1^{\prime \prime}$ & - & $181.0\left(\mathrm{C}-1^{\prime \prime}\right)$ \\
\hline $2^{\prime \prime}$ & $2.57\left(\mathrm{dq}, J=7.1 \mathrm{~Hz}, \mathrm{H}-2^{\prime \prime}\right)$ & $34.3\left(\mathrm{C}-2^{\prime \prime}\right)$ \\
\hline $3^{\prime \prime}$ & $1.18\left(\mathrm{~d}, J=7.1 \mathrm{~Hz}, \mathrm{H}-3^{\prime \prime}\right)$ & $18.5\left(\mathrm{C}-3^{\prime \prime}\right)$ \\
\hline $4^{\prime \prime}$ & $1.18\left(\mathrm{~d}, J=7.1 \mathrm{~Hz}, \mathrm{H}-4^{\prime \prime}\right)$ & $18.7\left(\mathrm{C}-4^{\prime \prime}\right)$ \\
\hline
\end{tabular}




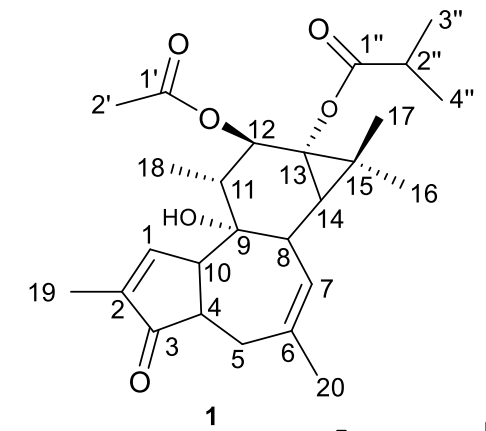

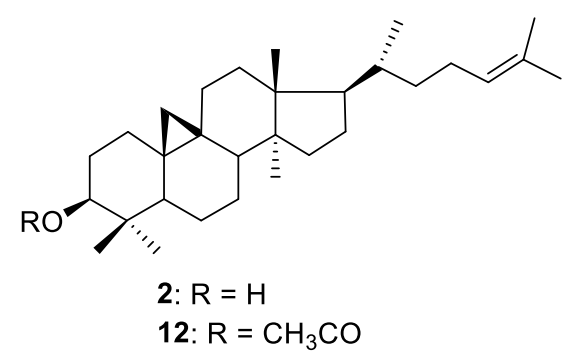

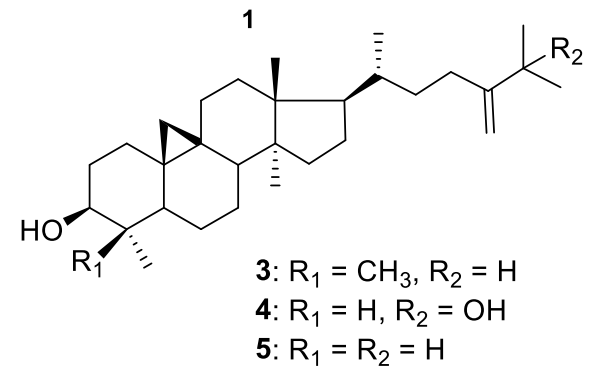<smiles>C=C(CC[C@H](C)C1CC[C@]2(C)C3=C(CC[C@]12C)[C@@]1(C)CC[C@H](O)[C@H](C)C1CC3)C(C)C</smiles>

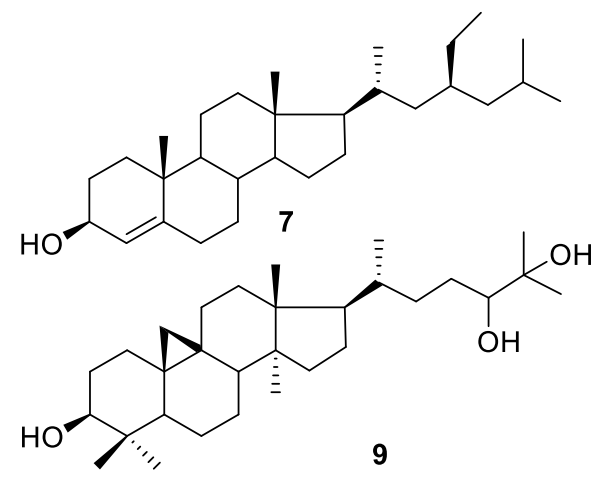<smiles>CC1=CCC([C@H](C)O)CC1</smiles>

Fig.1. Chemical structures of compounds 1-12, isolated from Euphorbia clementei.

Compounds 1-12 were tested for their cytotoxic activity against promyelocytic leukemia HL60 and human erythromyeloblastoid leukemia K562 cell lines (Table S1) and their chemical analogy allowed to get some structure activity relationships. Compounds 1, 2, 4, 6, 8, 9 and 12 exhibited weak cytotoxic effects against HL60 cell line, in a dose dependent manner, with $\mathrm{IC}_{50}$ values of $97,53,40$, 45, 52, 40 and $58 \mu \mathrm{M}$, respectively. Compounds 4 , 6, 8 and 9 showed weak cytotoxic effects against $\mathrm{K} 562$ cell line with $\mathrm{IC}_{50}$ values of $77.9,78,78.1$ and $77 \mu \mathrm{M}$, respectively. Compounds 1, 2 and 12 exhibited a selective cytotoxicity against HL60 cell line whereas, compounds 3, 5, 7, 10 and 11 were not significantly active on the two cell lines at the tested concentrations (Table S1). The phorbol derivative 1 was twofold less active than the active triterpene compounds against HL60 cell and its selective cytotoxicity was previously observed with tigliane derivatives on various cell lines (Fatope et al., 1996, Wang et al., 2015b). A moderate cytotoxic activity of Euphorbia triterpenes on various cell lines was also previously observed (Wang S. et al., 2016). Comparison of cytotoxic activities of compounds $\mathbf{4}$ and $\mathbf{5}$ indicated that a hydroxyl group at C-25 has a positive effect on the bioactivity. When comparing the cytotoxic effects of cycloartane derivatives $\mathbf{2 , 8}$ and $\mathbf{1 2}$ against K562 cell line, only compound $\mathbf{8}$ possessing $\mathrm{OH}$ group at C-25 showed activity. A comparison of the bioactivity of cycloartenol $\mathbf{2}$ and its acetate derivatives (12) in terms of chemical structure indicated that the substitution of an acetyl at C-3 in 12 did not influence the activity. Compound 3 carrying an additional methylene group at C-24 was relatively less active than the bioactive compounds 2 and 12, suggesting that an additional methylene group at C-24 of cycloartenol has a detrimental effect for the bioactivity. Comparison of the bioactivity of cycloeucalenol (5) and obtusifoliol (6) indicated that a methyl group at C-10 (6) is more favorable for the cytotoxic activity than methylene group (5). 
Table S1. Cytotoxic activities of compounds 1-12 against HL60 and K562 cell lines.*

\begin{tabular}{|c|c|c|}
\hline \multirow[t]{2}{*}{ Compound } & \multicolumn{2}{|c|}{$\mathrm{IC}_{50}$ values $(\mu \mathrm{M})$. } \\
\hline & HL60 & K562 \\
\hline 1 & $97 \pm 1.0$ & $-{ }^{b}$ \\
\hline 2 & $53 \pm 0.9$ & $-{ }^{a}$ \\
\hline 3 & $-{ }^{\mathrm{a}}$ & $-{ }^{\mathrm{a}}$ \\
\hline 4 & $40 \pm 0.7$ & $77.9 \pm 0.9$ \\
\hline 5 & $-{ }^{b}$ & $-{ }^{b}$ \\
\hline 6 & $45 \pm 0.4$ & $78 \pm 0.8$ \\
\hline 7 & $-\mathrm{b}$ & $-{ }^{b}$ \\
\hline 8 & $52 \pm 0.6$ & $78.1 \pm 2.0$ \\
\hline 9 & $40 \pm 0.6$ & $77 \pm 1.1$ \\
\hline 10 & $-\mathrm{b}$ & $-{ }^{b}$ \\
\hline 11 & $-{ }^{a}$ & $-{ }^{\mathrm{a}}$ \\
\hline 12 & $58 \pm 1.2$ & $-{ }^{a}$ \\
\hline Camptothecin $^{c}$ & $0.25 \pm 0.03$ & $0.30 \pm 0.05$ \\
\hline
\end{tabular}

\section{Experimental}

\subsection{General experimental procedures}

1D and 2D NMR spectra were performed in $\mathrm{CDCl}_{3}$ on Bruker Avance DRX III 500 instruments (Karlsruhe, Germany). HR-ESI-MS experiments were performed using a Micromass Q-TOF micro instrument (Manchester, UK). Optical rotations were determined in $\mathrm{CDCl}_{3}$ with a Perkin-Elmer 341 polarimeter. TLC was performed on pre-coated silica-gel $60 \mathrm{~F}_{254}$ Merck and were visualized under UV light at 254 and $366 \mathrm{~nm}$ and by spraying the dried plates with $50 \% \mathrm{H}_{2} \mathrm{SO}_{4}$, followed by heating. Centrifugal Partition Extraction (CPE) was performed on a lab-scale column of $303 \mathrm{~mL}$ capacity (FCPE300, Roussel et Robatel Kromaton, Annonay, France) containing 7 circular partition disks, engraved with a total of 231 oval partition twin-cells $(\approx 1 \mathrm{~mL}$ per twin cell). The CPE column was filled with the stationary phase at $200 \mathrm{rpm}$ by using a KNAUER Preparative 1800 V7115 pump (Berlin, Germany), the rotating was set at $1200 \mathrm{rpm}$ and a flow rate of $20 \mathrm{~mL} / \mathrm{min}$ was maintained over the whole experiment in the ascending mode. Flash chromatography was performed on a Grace Reveleris system with dual UV and ELSD detection equipped with a $40 \mathrm{~g} \mathrm{RP}-\mathrm{C}_{18}$ column. The mobile phase was water and methanol with a flow rate of $40 \mathrm{~mL} / \mathrm{min}$ and the effluents were monitored at 205 and $254 \mathrm{~nm}$.

\subsection{Plant material}

The roots and the latex of the plant Euphorbia clementei were collected in April 2013 from Khenchela (North Eastern Algerian). A voucher specimen (Ec.04.13) was deposited in the Herbarium of the Department of Chemistry, University Mentouri-Constantine, and authenticated by Prof. Gérard De Belair (University of Annaba, Algeria).

\subsection{Extraction and isolation}

The roots $(1 \mathrm{~kg})$ of $E$. clementei were macerated in $\mathrm{CHCl}_{3}(15 \mathrm{~L})$ for $72 \mathrm{~h}$ at room temperature. After filtration and concentration under low pressure, 21 $\mathrm{g}$ of $\mathrm{CHCl}_{3}$ extract was obtained. A part of the $\mathrm{CHCl}_{3}$ extract $(15 \mathrm{~g})$ was subjected to silica gel CC $(90 \times 5.5 \mathrm{~cm})$, elution was achieved using $(n-$ hexane-EtOAc, petroleum ether-EtOAc- $\mathrm{MeOH}$ ) with increasing polarity (1:0-0:1, 1:0:0-0:1:1). A total of 53 fractions (each $25 \mathrm{~mL}$ ) were obtained. Fraction 11 was subjected to silica gel CC eluted with petroleum ether -EtOAc (1:0-0:1) to afford 20 $\mathrm{mg}$ of compound 3. Fraction 12 was subjected to silica gel CC eluted with $n$-hexane-EtOAc (1:0-0:1) to give compounds $4(3.6 \mathrm{mg}), \mathbf{6}$ and $\mathbf{5}(20 \mathrm{mg})$. Fraction 13 was purified by using silica gel CC eluted with $n$-hexane-EtOAc (1:0-0:1) to afford compound $7(8 \mathrm{mg})$. Fraction 16 was purified by Flash chromatography over RP-18 eluted by $\mathrm{MeOH}-\mathrm{H}_{2} \mathrm{O}$ (75:25 to 100:0) in $30 \mathrm{~min}$, followed by preparative $\mathrm{TLC}$ in $\mathrm{CHCl}_{3}-\mathrm{MeOH}$ (9:1) on silica gel to afford compound $\mathbf{1}$ (3.6mg). Fraction 17 was subjected to silica gel $\mathrm{CC}$ eluted with petroleum ether-EtOAc (1:0-0:1) to afford compound 8 (18 $\mathrm{mg}$ ). Fractions 26-27 were purified on a Flash chromatography over RP-18 eluted by $\mathrm{MeOH}-\mathrm{H}_{2} \mathrm{O}$ (75:25 to 1:0) in $30 \mathrm{~min}$ to give compound 9 (40 $\mathrm{mg})$.

The latex of E. clementei was collected from the aerial part by incision, pressure on the rib and was concentrated under low pressure $(1.14 \mathrm{~g})$. The dried latex $(500 \mathrm{mg})$ was subjected to CPE fractionation. The biphasic solvent system composed of $n$ hexane-MeOH $(1: 1, v / v)$ in CPE was used in the ascending mode (i.e. the upper $n$-hexane phase was used as the mobile phase) to recover moderately non-polar compounds such as terpenoids derivatives from $500 \mathrm{mg}$ of dried latex. After pooling the collected fractions on the basis of TLC profile similarities, compounds $\mathbf{1 0}(23.5 \mathrm{mg}), \mathbf{1 1}$ (2 $\mathrm{mg}), 2(4.5 \mathrm{mg}), \mathbf{6}(6 \mathrm{mg})$, and $\mathbf{1 2}(7.6 \mathrm{mg})$ were obtained.

\subsubsection{4,20-dideoxy- $4 \alpha$-phorbol-12 $\beta$-acetate- $13 \alpha$ - isobutyrate (1)}


Colorless amorphous powder, $[\alpha]_{\mathrm{D}}{ }^{20}-16.78$ (c 0.30 , $\left.\mathrm{CHCl}_{3}\right) . \quad$ HR-ESI-MS $\mathrm{m} / z \quad 467.2404 \quad[\mathrm{M}+\mathrm{Na}]^{+}$, (calcd for $\mathrm{C}_{26} \mathrm{H}_{36} \mathrm{NaO}_{6}$; 467.2410). ${ }^{1} \mathrm{H}$ NMR (500 $\left.\mathrm{MHz}, \mathrm{CDCl}_{3}\right): \delta 7.20$ (s, H-1), 2.72 (dt, $J=4.2$ and $6.3 \mathrm{~Hz}, \mathrm{H}-4), 2.38$ (dd, $J=15.4$ and $4.7 \mathrm{~Hz}, \mathrm{H}-5 \mathrm{a}$ ), 3.45 (brd, $J=15.4 \mathrm{~Hz}, \mathrm{H}-5 \mathrm{~b}$ ), 4.75 (s, H-7), 1.90 (s, $\mathrm{H}-8$ ), 3.42 (m, H-10), 1.70 (dd, $J=10.4$ and $6.2 \mathrm{~Hz}$, H-11), 5.45 (d, $J=10.4$ Hz, H-12), 0.74 (d, $J=5.1$ Hz, H-14), 1.23 (s, H-16), 1.20 (s, H-17), 1.09 (d, J $=6.2 \mathrm{~Hz}, \mathrm{H}-18), 1.82(\mathrm{~s}, \mathrm{H}-19), 1.77$ (s, H-20), 2.15 (s, H-2'), 2.57 (sept, $\left.J=7.1 \mathrm{~Hz}, \mathrm{H}-2^{\prime \prime}\right), 1.18$ $\left(\mathrm{d}, J=7.1 \mathrm{~Hz}, \mathrm{H}-3^{\prime \prime}\right), 1.18$ (d, $\left.J=7.1 \mathrm{~Hz}, \mathrm{H}-4{ }^{\prime \prime}\right) .{ }^{13} \mathrm{C}$ NMR (125 MHz, $\mathrm{CDCl}_{3}$ ) : $\delta 155.6(\mathrm{C}-1), 143.2(\mathrm{C}-$ 2), 211.8 (C-3), 49.3 (C-4), 30.0 (C-5), 134.8 (C-6), 124.3 (C-7), 40.9 (C-8), 78.0 (C-9), 47.1 (C-10), 43.2 (C-11), 76.1(C-12), 64.9 (C-13), 37.6 (C-14), 25.4 (C-15), 16.4 (C-16), 24.2 (C-17), 11.9 (C-18), 10.5 (C-19), 28.9 (C-20), $170.6\left(\mathrm{C}-1^{\prime}\right), 21.1\left(\mathrm{C}-2^{\prime}\right)$, $181.0\left(\mathrm{C}-1^{\prime \prime}\right), 34.3\left(\mathrm{C}-2^{\prime \prime}\right), 18.5\left(\mathrm{C}-3^{\prime \prime}\right), 18.7$ (C-4").

\subsection{Cell proliferation assay.}

Promyelocytic leukemia HL60 and human erythromyeloblastoid leukemia K562 cells were spread onto 96-well flat-bottom plates at a density of 2500 cells per well, and then incubated in RPMI
1640 Medium supplemented with $10 \%$ fetal bovine serum and $1 \%$ antibiotics. The cells were then treated with the tested compounds for $72 \mathrm{~h}$. The cell cultures were then analyzed using (3-[4,5dimethylthiazol-2-yl]-2,5-diphenyltetrazolium bromide; thiazolyl blue) salt (MTT) according to the manufacturer's instructions (Promega Corporation, Charbonnières, France). Camptothecin was used as positive control with the same conduction. MTS is reduced by cells into a colored formazan product. Absorbance was analyzed at a wavelength of $540 \mathrm{~nm}$ with a Multiskan Ex microplate absorbance reader (Thermo Scientific, Paris, France). The results of these assays were used to obtain the dose-response curves from which $\mathrm{IC}_{50}$ values were determined. The values represent averages of three independent experiments.

\subsection{Statistical analysis.}

Results are expressed as mean \pm standard deviation (SD) from three independent experiments. Statistical differences were calculated using a oneway analysis of variance (ANOVA). Difference in means between two treatment groups was compared by Student's $t$-test. Significance was considered when $p<0.05$.

\section{Acknowledgements.}

The authors are grateful to MESRS, Algeria for the Profas grant to Mr. Abbes Benmerache, to CNRS, Conseil Régional Champagne Ardenne, Conseil Général de la Marne, Ministry of Higher Education and Research (MESR), and to the PIANET CPER project for financial support.

\section{Supporting Information.}

HR-ESI-MS, ${ }^{1} \mathrm{H}$ and ${ }^{13} \mathrm{C}$ NMR, COSY, HMBC and ROESY spectra for compound $\mathbf{1}$ and cytotoxic activities of compounds 1-12 against HL60 and K562 cell lines.

\section{References}

Abdel-Monem, A.R., Abdel-Sattar, E., Harraz, F.M., Petereit, F., 2008. Chemical Investigation of Euphorbia schimperi. C. Presl. Rec. Nat. Prod. 2, 39-45.

Aichour, S., Haba, H., Benkhaled, M., Harakat, D., Lavaud, C., 2014. Terpenoids and other constituents from Euphorbia bupleuroides. Phytochem. Lett. 10, 198-203.

Alberto Marco, J., Sanz-Cervera, J.F., Checa, J., Palomares, Emilio, Manuel Fraga, B., 1999., Jatrophane and tigliane diterpenes from the latex of Euphorbia obtusifolia. Phytochemistry. 52, 479-485.

Chaturvedula, V.S.P., Prakash, I., 2012. Isolation of stigmasterol and $\beta$-sitosterol from the dichloromethane extract of Rubus suavissimus. Int. Curr. Pharam. J. 9, 239-242.

Consolacion, Y.R., Dinah L.E., Esperanza Maribel, G.A., Ramon S.F., 2013. Chemical constituents of Cinnamomum cebuense. Chin. J. Nat. Med. 2013, 11(3): 0264-0268.

De Pascual Teresa, J., Urones, J., Marcos, I., Basabe, P., Cuadrado, M.S., Fernandez Moro, R., 1987. Triterpenes from Euphorbia broteri. Phytochemistry 26, 1767-1776.
Deng, B., Mu, S.Z., Zhang, J.X., Hao, X.J., 2010. New diterpenoids from the roots of Euphorbia ebracteolata Hayata. Nat. Prod. Res. 24,1503-1509.

Duarte, N., Gyemant, N., Abreu, P.M., Molnar, J., Ferreira, M.J. 2006. New macrocyclic lathyrane diterpenes, from Euphorbia lagascae, as inhibitors of multidrug resistance of tumour cells. Planta Med. 72, 162-168.

El-Sherei, M.M., Islam, W.T., El-Dine, R.S., El-Toumy, S.A., Ahmed S.R., 2015. Phytochemical investigation of the cytotoxic latex of Euphorbia cooperi N.E.Br. Aust. J. Basic and Appl. Sci. 9, 488-493.

Fatope, M.O., Zeng, L., Ohayaga, J.E., Shi, G., McLaughlin, J.L. 1996. Selectively cytotoxic diterpenes from Euphorbia poisonii. J. Med. Chem. 39, 1005-1008.

Gao, J., Chen, Q.-B., Liu, Y.-Q., Xin X.-L., Yili, A., Aisa, H.A. 2016. Diterpenoid constituents of Euphorbia macrorrhiza. Phytochemistry 122, 246-253.

Ghanadian, M., Ayatollahi, A.M., Mesaik, M.A., Afsharypuor, S., Abdalla O.M., Kobarfard, F., 2011.New tigliane type 
diterpenoids from Euphorbia aellenii Rech. f. with immunomodulatory activity. Res Pharm Sci. 6, 35-41.

Ghanadian, M., Saeidi, H., Aghaei, M., Rahiminejad, M.R., Ahmadi, E., Ayatollahi, S.M., Choudhary, M. I., Bahmani, B., 2015. New jatrophane diterpenes from Euphorbia osyridea with proapoptotic effects on ovarian cancer cells, Phytochem. Lett. 12, 302-307.

Haba, H., Lavaud, C., Harkat, H., Alabdul Magid, A., Marcourt, L., Benkhaled, M., 2007. Diterpenoids and triterpenoids from Euphorbia guyoniana. Phytochemistry 68, 1255-1260.

Haba, H., Marcourt, L., Benkhaled, M., Long, C., 2013. Minor ent-abietane diterpenoids from Euphorbia guyoniana. Nat. Prod. Commun. 8, 1519-1522.

Hohmann, J., Evanics, F., Dombi, G., Szabó, P., 2001. Salicifoline and Salicinolide, new diterpene polyesters from Euphorbia salicifolia. Tetrahedron Lett. 42, 6581-6584.

Jassbiet, A.R., 2006. Chemistry and biological activity of secondary metabolites in Euphorbia from Iran. Phytochemistry 67, 1977-1984.

Li, W., Cao, P., Zang, Z., Ma, Y.T., Liu, F.Y., Li F., Wu X.H., Huang S.X., Zhao, Y., 2015. Two new triterpene rhamnosides from Euphorbia dracunculoides Lam. Phytochem. Lett. 12, 168-172.

Mohann, B.G., Hattori, M., Yasuhiro, T., Kikuchi, T., Namba, T., 1990. Constituents of the latex of Euphorbia amiquorum. Phytochemistry 29, 1625-1628.

Mohd Nasuha, N.A., Choo, Y.M., 2015. A new flavone from Malaysia Borneo Marsdenia tinctoria. Nat Prod Res. 30, 1-

Pusztai, R., Ferreira, M.J., Duarte, N., Engi, H., Molnar, J., 2007. Macrocyclic lathyrane diterpenes as antitumor promoters. Anticancer Res. 27, 201-205.

Quezel, P., Santa, S., 1963. Nouvelle Flore de l'Algérie et des régions désertiques méridionales, vol. 1-2. CNRS, Paris.

Shadi, S., Saeidi, H., Ghanadian, M., Rahimnejad, M.R., Aghaei, M., Ayatollahi, S.M., Choudhary, M.I., 2015. New macrocyclic diterpenes from Euphorbia connata Boiss. with cytotoxic activities on human breast cancer cell lines. Nat. Prod. Res. 29, 607-614.

Singla, A.K, Pathak, K., 1990. Phytoconstituents of Euphorbia species. Fitoterapia 61, 483-516.

Sobottka, A.M., Görick, C., Melzig, M.F., 2016. Analysis of diterpenoid compounds from the latex of two Euphorbiaceae by liquid chromatography-electrospray ionisation mass spectrometry. Nat. Prod. Res. 30, 1941-1944.Wan, L.-S., Chu, R., Peng, X.-R., Zhu, G.-L., Yu, M.-Y, Li, L., Zhou,
L., Lu, S.-Y., Dong, J.-R., Zhang, Z.-R., Li, Y., Qiu, M.-H. 2016. Pepluane and Paraliane Diterpenoids from Euphorbia peplus with Potential Anti-inflammatory Activity. J. Nat. Prod. 79, 1628-1634.

Wang, J.F., Yang, S.H., Liu Y.Q., Li D.X., He W.J., Zhang, X.X., Liu, Y.H., Zhou, X.J., 2015. Five new phorbol esters with cytotoxic and selective anti-inflammatory activities from Croton tiglium. Bioorg. Med. Chem. Lett. 25, 19861989.

Wang, L., Yang, J., Chi, Y.Q., Ouyang, W.B., Zang, Z., Huang, S.X., Cao, P., Zhao, Y., 2015a. A new myrsinol-type diterpene polyester from Euphorbia dracunculoides Lam. Nat. Prod. Res. 29, 1406-1413.

Wang, L., Ma, Y.-T., Sun, Q.-Y., Li, X.-N., Yan, Y., Yang, J., Yang F.-M., Liu, F.-Y., Zang, Z., Wu, X.-H., Huang, S.X., Zhao, Y. 2015b Structurally diversified diterpenoids from Euphorbia dracunculoides. Tetrahedron 71, 54845493.

Wang, K., Yu, H., Wu, H., Wang, X., Pan, Y., Chen, Y., Liu, L., Jin, Y., Zhang, C., 2015. A new casbane diterpene from Euphorbia pekinensis. Nat. Prod. Res. 29, 15, 1456-1460.

Wang, M., Wang, Q., Wei, Q., Li, J., Guo, C., Yang, B., Kuang, H., $2016 . \quad$ Two new ent-atisanes from the root of Euphorbia fischeriana Steud. Nat. Prod. Res. 30, 144-149.

Wang, S., Liang, H., Zhao, Y., Wang G., Yao H., Kasimu R., Wu Z.,. Li Y., Huang, J., Wang, J. 2016. New triterpenoids from the latex of Euphorbia resinifera Berg. Fitoterapia 108, 33-40.

Wu, D., Sorg, B., Hecker, E., 1994. Oligo- and macrocyclic diterpenes in Thymelaeaceae and Euphorbiaceae occurring and utilized in Yunnan (Southwest China) 6. Tigliane type diterpene esters from latex of Euphorbia prolifera. Phytother. Res. 8, 95-99.

Yang, C.M., Cheng, H.Y., Lin, T.C., Chiang, L.C., Lin, C.C., 2005. Euphorbia thymifolia suppresses herpessimplex virus2 infection by directly inactivating virus infectivity. Clin Exp Pharmacol Physiol. 32, 346-349.

Yang, D.S., Peng, W.B., Li, Z.L., Wang, X., Wei, J.G., He, Q.X., Yang, Y.P., Liu, K.C., Li, X.L., 2014. Chemical constituents from Euphorbia stracheyi and their biological activities. Fitoterapia 97, 211-218.

Zhang, B.-Y., Wang, H., Li, X.-D., Du, Z.-Z., Wu, H.-F., Shan, J.-W., Zhang, X.-F, 2012. Chemical constituents of Euphorbia tangutica. Nat. Prod. Res. 26, 2309-2315. 